\title{
In the wake of the coup
}

\section{Moscow}

THE failure of the attempted coup d'etat in the Soviet Union has brought increased freedom, but also an increased chance of chaos. The future of science and technology is still up in the air.

\section{Russia's Silicon Valley}

ZELENOGRAD, one of Moscow's satellite towns, is known as the 'Silicon Valley of the Soviet Union'. There much of the electronics work for the military is done, but the town was also a centre of rebels fighting the totalitarian system, and it has perhaps one of the brightest economic futures of any place in the country.

On 19 August, the day of the coup, as early as 9 a.m., L. Ivaniutin, general director of the scientific and production association Elma, spoke on the radio and called upon the personnel to boycott the junta's directive. Elma is the only Soviet producer of basic materials for electronics. For many years the enterprise had suffered at the hands of the All-Union Ministry, which fired or fettered the most intellectually gifted or active workers, but Elma will now come under the authority of the government of the Russian Republic. Several other Zelenograd enterprises are also getting out from under the authority of the military-industrial complex.

With the screen of secrecy torn off, it appears that the electronics industry is in mostly poor condition. Soviet computers are not competitive with foreign machines and cannot be sold even for the lowest prices, putting Soviet producers at the edge of bankruptcy.

Nonetheless, with its highly qualified specialists, Zelenograd is attracting foreign businessmen. For instance, the US company Cypress Semiconductor signed an agreement last year to manufacture computer chips designed by Soviet researchers and pay royalties for those designs. Cypress president T.J. Rogers, who visited Zelenograd last year, says that although the Soviet semiconductor manufacturing technology is six or seven years behind that of the West, their design work is excellent. "I saw a dozen ideas that would have triggered start-ups in Silicon Valley that were just sitting on someone's desk," he says.

Rogers says he was approached by Soviet chip designers who pleaded with him to manufacture their circuits, which are too advanced to be made with Soviet equipment. He has high hopes for future cooperation, but "with all the turmoil going on, we haven't really gotten too far."

Unfortunately, the Soviets have little more than design skills to offer for joint ventures with the West. They can provide the land for production facilities, and perhaps some obsolete equipment for low- cost assembling operations. But although difficulties lie ahead, there is a great hope that the city of Zelenograd, which stood up to the coup d'etat, will have the same persistence in solving economical problems and raising the scientific and technical level of production.

\section{Who will own Mir?}

THERE are widespread rumours that one of the best Soviet space vehicles, the orbital space probe Mir, is for sale. Newspapers have even mentioned the approximate asking price: $\$ 600-800$ million.

$\mathrm{Yu}$. Semenov of the scientific and production association 'Energia', which specializes in the development, production and operation of space equipment, denies these rumours. He does admit, however, that even the once-inviolate Soviet space programme has not been left untouched by the chaos wracking the country. So what will happen to Mir?

Sharp cuts in state allocations have forced the space programme to seek new sources of revenue. Semenov believes that the only way out of the present situation is

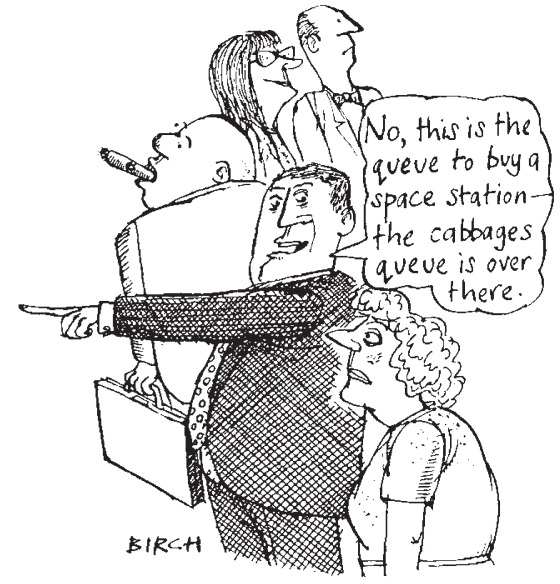

to create joint-stock companies with foreign companies and to transform Mir into an international scientific laboratory. "We have got several offers already, some of them quite serious," he says, so Mir is at present in no danger of being grounded. "We shall certainly fulfil all our obligations concerning the space flights of Austrian, German, and French astronauts. Austrian astronauts will start off as soon as October 2."

Energia is planning two more modules to dock with Mir, one for optical studies and one to do ecological work. By 1994, after a rearrangement of the modules, the association hopes to change the basic unit and to start the construction of a secondgeneration Mir probe, which should be finished by 2000 , assuming that money is found for the project.

Financial problems are not the only ones facing Mir - even the ownership of the station is in doubt. Decades of socalled 'public ownership' in the Soviet Union have created a situation in which nobody knows who the real owner is of this or that property, and successful privatization of the space industry will be of no less importance than privatization on land.

Helene Knorre

\section{LONDON ZOO}

\section{Management under fire}

\section{London}

THE embattled management of London Zoo came under attack last week from many of the fellows of the Zoological Society of London, who argued that the present team must be replaced by a crisis management committee if the closure of the zoo's Regent's Park site is to be prevented.

At the end of a turbulent annual general meeting, a motion of no confidence in the zoo's management was dismissed by society president Avrion Mitchison on a procedural point. But supporters of that motion plan to request another meeting of the society before the end of the year, to ask for changes in the zoo's management.

Colin Tudge, a writer on zoology and conservation, says the London Zoo has been travelling down the wrong path for the past decade: while other leading zoos have streamlined their collections, basing public exhibits around their work in captive breeding and conservation, London has essentially remained a "nineteenth century menagerie". The present efforts by the zoo's management to attract more than $£ 12$ million of investment to convert the Regent's Park site into a centre housing fewer animals and stressing the Zoological Society's work in conservation could be a step in the right direction, says Tudge, but it is one that should have been taken several years ago.

David Jones, who heads the team that runs the zoo's two sites for the society, says replacing the management now would jeopardize negotiations with investors aimed at securing the zoo's financial future.

But Jones's critics say it is the continued presence of the present management that has stymied attempts to attract funds from the government and the private sector. Trevor Poole, society fellow and deputy director of the Universities Federation for Animal Welfare, wants the zoo's management handed over to a small committee of experienced directors from other British zoos, many of which are financially healthy.

The governing council of the Zoological Society has so far shown no sign of relinquishing its support for the present management. But if no promises of major private investment are made in the next few months, that loyalty may be tested. "I wouldn't rule out any options," says Peter Holwell, principal of the University of London and the society's new treasurer.

Peter Aldhous 